\title{
Differences in $\mathrm{Ca}^{2+}$-management between the ventricle of two species of Neotropical teleosts: the jeju, Hoplerythrinus unitaeniatus (Spix \& Agassiz, 1829), and the acara, Geophagus brasiliensis (Quoy \& Gaimard, 1824)
}

\author{
Monica Jones Costa ${ }^{1}$, Francisco Tadeu Rantin² and Ana Lúcia Kalinin²
}

This study analyzed the physiological role of the cardiac sarcoplasmic reticulum (SR) of two neotropical teleosts, the jeju, Hoplerythrinus unitaeniatus (Erythrinidae), and the acara, Geophagus brasiliensis (Cichlidae). While the in vivo heart frequency $\left(f_{\mathrm{H}}-\mathrm{bpm}\right)$ of acara $(79.6 \pm 6.6)$ was higher than that of the jeju $(50.3 \pm 2.7)$, the opposite was observed for the ventricular inotropism $\left(\mathrm{Fc}-\mathrm{mN} / \mathrm{mm}^{2}\right)$ at $12 \mathrm{bpm}($ acara $=28.66 \pm 1.86 \mathrm{vs}$. jeju $=36.09 \pm 1.67)$. A 5 min diastolic pause resulted in a strong

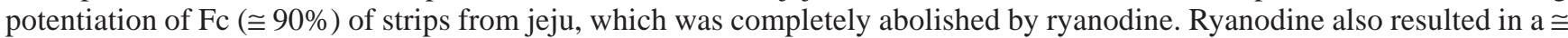
$20 \%$ decrease in the Fc developed by strips from jeju at both subphysiological (12 bpm) and physiological (in vivo) frequencies. However, this effect of ryanodine reducing the Fc from jeju was completely compensated by adrenaline increments $\left(10^{-9}\right.$ and $10^{-}$ ${ }^{6} \mathrm{M}$ ). In contrast, strips from acara were irresponsive to ryanodine, irrespective of the stimulation frequency, and increases in adrenaline concentration (to $10^{-9}$ and $10^{-6} \mathrm{M}$ ) further increased Fc. These results reinforce the hypothesis of the functionality of the SR as a common trait in neotropical ostariophysian (as jeju), while in acanthopterygians (as acara) it seems to be functional mainly in 'athletic' species.

O presente estudo analisou o papel fisiológico desempenhado pelo retículo sarcoplasmático (RS) de duas espécies de teleósteos neotropicais, o jeju, Hoplerythrinus unitaeniatus (Erythrinidae), e o acará, Geophagus brasiliensis (Cichlidae). Enquanto a frequência cardíaca registrada in vivo $\left(f_{\mathrm{H}}\right.$ - bpm) para o acará (79.6 \pm 6.6$)$ foi superior àquela observada para o jeju (50.3 \pm 2.7$)$, resposta inversa foi verificada para o inotropismo ventricular $\left(\mathrm{Fc}-\mathrm{mN} / \mathrm{mm}^{2}\right)$ na frequência de estimulação de 12 bpm (acará = $28.66 \pm 1.86$ vs. jeju $=36.09 \pm 1.67)$. Uma pausa diastólica de 5 min resultou em uma expressiva potenciação da Fc $(\cong 90 \%)$ das tiras de jeju, a qual foi completamente abolida pela rianodina. A rianodina também resultou em um decréscimo de $\cong 20 \%$ na Fc desenvolvida pelas tiras de jeju tanto a frequências sub-fisiológicas (12 bpm) quanto fisiológicas (in vivo). No entanto, o decréscimo da Fc promovido pela rianodina foi completamente compensado pela adição de adrenalina $\left(10^{-9}\right.$ e $\left.10^{-6} \mathrm{M}\right)$. Em contraste, as tiras de acará foram irresponsivas à rianodina, independentemente da frequência de estimulação utilizada, fazendo com que a adição de adrenalina $\left(10^{-9}\right.$ e $\left.10^{-6} \mathrm{M}\right)$ resultasse em incrementos ainda maiores da Fc. Esses resultados reforçam a hipótese de que a funcionalidade do RS seja uma característica comum aos ostariofíseos neotropicais (como o jeju), enquanto nos acantopterígios (como o acará) esta organela parece ser funcional principalmente em espécies ativas.

Key words: Excitation-contraction coupling, Ryanodine, Sarcoplasmic reticulum, Ventricle strips.

\section{Introduction}

The significance of the sarcoplasmic reticulum (SR) to the contraction-relaxation cycle of the cardiac muscle varies greatly among different vertebrate classes, among different species within the same phylogenetic group and during the ontogenetic development of an individual (Aho \& Vornanen,
1998). In the mammalian heart, $\mathrm{Ca}^{2+}$ entering the cell during the action potential enhances the release of further $\mathrm{Ca}^{2+}$ from the SR to support the contractile process (Fabiato, 1983). In contrast, in frogs and teleost fish, $\mathrm{Ca}^{2+}$ required for contractility is derived under most circumstances primarily via transport across the sarcolemma, while $\mathrm{Ca}^{2+}$ stored inside the SR plays a secondary (if any) role (Tibbits et al., 1991).

${ }^{1}$ Universidade Federal de São Carlos (UFSCar), Campus Sorocaba. Rodovia João Leme dos Santos (SP-264), km 110, 13565-905 Sorocaba, SP, Brazil.monica@ufscar.br

${ }^{2}$ Department of Physiological Sciences, Universidade Federal de São Carlos (UFSCar), Rodovia Washington Luiz, km 235, São Carlos, SP, Brazil. 
Although present, the role of the SR in the beat-to-beat regulation of contractions of the teleost heart requires further definition, as ryanodine, which impedes SR function, has a negative impact only at rates below the physiological range of frequencies in most species (Driedzic \& Gesser, 1994). Ryanodine is a plant alkaloid that binds specifically and irreversibly to $\mathrm{SR} \mathrm{Ca}^{2+}$-release channels, thereby reducing the functional importance of SR for the excitation-contraction (E-C) coupling (Nayler et al., 1970; Rousseau et al., 1987; Coronado et al., 1994; Bers, 2001). Species-specific differences are also evident in the inhibition of contraction by ryanodine. In crucian carp heart, ryanodine has no effect on ventricular contraction (Vornanen, 1996). In rainbow trout ventricle, ryanodine slightly reduces the force of contraction, especially at high experimental temperatures and at low contraction frequencies (Keen et al., 1994; Shiels \& Farrell, 1997), and in the atrium and ventricle of tunas, ryanodine exerts a clear negative inotropic effect (Keen et al., 1992; Tibbits, 1996; Shiels et al., 1999, 2002), even at physiological frequencies.

These findings suggest that more active fish have a higher $\mathrm{Ca}^{2+}$-handling capacity in the cardiac SR than less active species. However, studies on the effect of ryanodine on the ventricular muscle of tropical fish failed to demonstrate a direct relationship among the level of activity and the functionality of the SR, since ventricle strips from some active species (Olle, 2003; Anelli Jr. et al., 2004; Rivaroli et al., 2006) or fish adapted to acute transitions to high temperatures (Rantin et al., 1998; Costa et al., 2000), did not show a postrest potentiation of twitch force that could be abolished by ryanodine. Indeed, in highly sedentary tropical fish ryanodine had a strong inhibitory effect on postrest force as well as at physiological frequencies (Costa et al., 2004; Rivaroli et al., 2006).

The results indicate a phylogenetical trait determining the functionality of the SR in tropical fish, rather than its presence being exclusively determined by a high metabolic demand as a result of increased temperatures or activity. Therefore, in the present study we were interested in comparing the effect of ryanodine on the cardiac inotropism of two neotropical teleosts which are phylogenetically distant and that present different levels of activity: the relatively sedentary jeju, Hoplerythrinus unitaeniatus (Superorder Ostariophysi), and the more active acara, Geophagus brasiliensis (Superorder Acanthopterygii). Moreover, another question to be answered was: to what extent an adrenergic stimulation can compensate the absence of a functional SR or its blockade by ryanodine? Adrenaline is found in the blood reaching the heart of resting fish at a concentration between 10 and $100 \mathrm{nM}$ (Butler et al., 1986), but its plasmatic levels rise in stressful conditions (e.g., exercise and temperature) to $10 \mu \mathrm{M}$ (Farrell, 1984). Therefore, further experiments were made to determine whether a tonic adrenergic stimulation $\left(10^{-9} \mathrm{M}\right)$ and an adrenaline concentration observed at fish plasma during stress conditions $\left(10^{-6} \mathrm{M}\right)$ could maximize trans-sarcolemmal $\mathrm{Ca}^{2+}$-influx and then partially or completely compensate the blockade of the SR function by ryanodine in species in which this organelle is functional.

\section{Material and Methods}

\section{Animals}

Adult specimens of jeju, Hoplerythrinus unitaeniatus (mean mass $209 \pm 12 \mathrm{~g}$, both sexes), were collected in the Paraná River Basin near Bataguaçu, Mato Grosso do Sul State (Central Brazil), while acara, Geophagus brasiliensis (mean mass $75 \pm 8 \mathrm{~g}$, both sexes), were obtained from local ponds within the campus area of the Universidade Federal de São Carlos, Southeast Brazil. In the laboratory fish were maintained in $1000 \mathrm{~L}$ holding tanks supplied with aerated water at $25 \pm$ $1^{\circ} \mathrm{C}$ (acclimation temperature) for at least four weeks prior to experimentation (photoperiod $12 \mathrm{~h}: 12 \mathrm{~h} \mathrm{~L}: \mathrm{D}$ ). The animals were fed twice a day with commercial fish food pellets. For the specimens used in the in vivo experiments, food was withheld $24 \mathrm{~h}$ before experimentation.

\section{'In vivo' heart rate}

In order to estimate the potential contribution of the SR at physiological frequencies, the heart rate $\left(f_{\mathrm{H}}-\mathrm{bpm}\right)$ was measured by electrocardiography. An electrode was placed in a ventral position between the gills and the heart, and a second electrode was also implanted ventrally, but closer to the pelvic fins. A reference electrode was located in the water of the experimental chamber (for details see Glass et al., 1991 and Rantin et al., 1993). The electrode set was connected to a universal coupler of a Narco Narcotrace 40 recorder (Narco Bio Systems, TX, USA).

To implant the electrodes, fish were immersed in a benzocaine solution $\left(0.1\right.$ g. $\left.\mathrm{L}^{-1}\right)$. This level of anesthesia allowed spontaneous breathing. After surgery, fish were placed in a holding PVC tube. After a recovery period of $12 \mathrm{~h}$, $f_{\mathrm{H}}$ was measured at $25^{\circ} \mathrm{C}$.

\section{'In vitro' experiments}

Fish were stunned by a blow to the head, the spine was cut and the heart was carefully excised and placed in ice-cooled saline. The ventricle was isolated and two strips (diameter $\cong 1$ $\mathrm{mm}$ ) were excised from the heart and transferred to a $50 \mathrm{~mL}$ water-jacketed organ bath containing: $100 \mathrm{mM} \mathrm{NaCl}, 10 \mathrm{mM}$ $\mathrm{KCl}, 1.2 \mathrm{mM} \mathrm{MgSO}_{4}, 1.5 \mathrm{mM} \mathrm{NaH}_{2} \mathrm{PO}_{4}, 27 \mathrm{mM} \mathrm{NaHCO}_{3}, 1.25$ $\mathrm{mM} \mathrm{CaCl}_{2}$ and $10 \mathrm{mM}$ glucose and bubbled throughout the experiment with a $2 \%$ carbogenic gas mixture $\left(\mathrm{pH} 7.5\right.$ at $25^{\circ} \mathrm{C}$ ).

Preparations were suspended using surgical silk to have one end attached to a platinum chain which hung from a NARCO F-60 isometric force transducer (Narco Bio Systems, TX, USA), and the other end was tied around a platinum electrode. This electrode and one placed in the bath were connected to a SD9 Grass stimulator (Grass, MA, USA) sending electrical square pulses and having a duration of 8 ms and a voltage $50 \%$ above the threshold in order to provide a security margin and assuring maximal stimulation throughout the experiment. Preparations were stretched to obtain a twitch tension at the maximum of the length-twitch tension relation. Twitch tension was then allowed to stabilize for about $30 \mathrm{~min}$ at $12 \mathrm{bpm}$ before each protocol (see below). 


\section{Protocol 1}

In this protocol, after the stabilization period (30 min, see above), $10 \mu \mathrm{M}$ of ryanodine (Sigma) (SR function blocker) was added to the muscle bath, and the twitch force $\left(\mathrm{mN} / \mathrm{mm}^{2}\right)$ developed before (control) and 40 min after adding ryanodine were compared. This experimental protocol was performed to determine if the SR had any physiological role at subphysiological frequencies (12 bpm).

\section{Protocol 2}

The purpose of protocol 2 was to determine whether the ventricle of each species presented a sarcoplasmic reticulum or not that could potentially accumulate calcium during the prolonged rest (see Thomas et al., 1986), as indicated by a postrest potentiation of twitch force (represented as a percentage (\%) of the last contraction registered before pause). After a stabilization period at $12 \mathrm{bpm}$ (30 min; see above), ventricle strips from both species were subjected to a prolonged and non-physiological diastolic pause of $5 \mathrm{~min}$, and the first postrest contraction with and without pretreatment with $10 \mu \mathrm{M}$ of ryanodine were compared to each other and also to the force developed before rest.

\section{Protocol 3}

To determine the relative contribution of the SR in force development over a wide range of frequencies, including in vivo range (as determined by ECG recordings in the in vivo experiments, see above), the force-frequency relationship was determined with and without pre-treatment with $10 \mu \mathrm{M}$ of ryanodine. Following the 30 min stabilization period, pacing frequency was increased in $12 \mathrm{bpm}$ increments from $12 \mathrm{bpm}$ until the frequency in which the muscle failed to show regular contractions.

\section{Protocol 4}

Protocol 4 was similar to protocol 3, but 40 min after adding ryanodine, $10^{-9} \mathrm{M}$ of adrenaline (Merck) was added to the bath. After a 7 min stabilization period, ventricle strips were subjected to a force-frequency trial, as described above, and then back to $12 \mathrm{bpm}$. When the twitch was stabilized again at $12 \mathrm{bpm}$, adrenaline concentration was then increased to $10^{-6} \mathrm{M}$, and after $7 \mathrm{~min}$, another force-frequency trial was carried out.

\section{Data Presentation and analysis}

The inotropic responsiveness of the ventricle strips to each experimental condition was measured by means of the twitch force ( $\mathrm{Fc}-\mathrm{mN} / \mathrm{mm}^{2}$ or \% initial values), while the in vivo chronotropism is presented as bpm (QRS intervals . $\mathrm{min}^{-1}$ ).

Results are presented as mean \pm S.E. $(n=12)$. In all experiments, levels of significance with respect to the initial values obtained in the same experimental protocol were assessed with One-way Analysis of Variance (ANOVA) followed by Bartlett's test for homogeneity of variances and the Tukey-Kramer multiple comparisons test ( $<<0.05$ ). Additionally, the Mann-Whitney test was used to compare the results obtained at different protocols $(\mathrm{p}<0.05)$.

\section{Results}

The resting heart rate measured in vivo by electrocardiography at acclimation temperature $\left(25^{\circ} \mathrm{C}\right)$ was $50.3 \pm 2.7 \mathrm{bpm}$ for jeju (mean \pm S.E.; $\mathrm{n}=12$ ) and $79.6 \pm 6.6 \mathrm{bpm}$ for acara (mean \pm S.E.; $\mathrm{n}=12$ ). Additionally, after stabilization at $12 \mathrm{bpm}$ at acclimation temperature $\left(25^{\circ} \mathrm{C}\right)$, the twitch force developed by ventricle strips of jeju and acara at steadystate $(12 \mathrm{bpm})$ were $36.09 \pm 1.67 \mathrm{mN} / \mathrm{mm}^{2}($ mean \pm S.E.; $\mathrm{n}=12$ ) and $28.66 \pm 1.86 \mathrm{mN} / \mathrm{mm}^{2}$ (mean \pm S.E.; $\mathrm{n}=12$ ), respectively. However, 40 min after treatment with $10 \mu \mathrm{M}$ of ryanodine, the twitch force of ventricle strips from jeju decreased approximately $20 \%$, reaching force values similar to those observed for acara (Table 1). In contrast, the steady-state force (12 bpm) developed by ventricle strips from acara after treatment with ryanodine remained unchanged $(p>0.05)$ in relation to the control.

The relative contribution of the $\mathrm{Ca}^{2+}$ stored in the SR to force generation after a diastolic pause of 5 min with and without (control) pre-treatment with $10 \mu \mathrm{M}$ of ryanodine is presented in Fig. 1. The non-physiological diastolic pause resulted in an increase of $\cong 90 \%(p<0.05)$ in the force developed by ventricle strips from jeju in relation to the steady-state contractions. This postrest potentiation of the twitch force developed by ventricle strips from jeju was completely abolished by ryanodine. In contrast, the postrest contraction force of control and ryanodine-treated ventricle strips from acara remained unchanged $(p>0.05)$ in relation to the steady-state contractions.

In the force-frequency experiments, ventricle strips from both species showed a negative force-frequency relationship (Fig. 2), with a steeper curve presented by jeju in all protocols. However, for control preparations, initial absolute values of the force developed by strips from jeju were higher than those observed in acara (Table 1, Fig. 2a), while the force measured when the in vivo frequency was reached became similar for jeju $\left(20.40 \pm 0.94 \mathrm{mN} / \mathrm{mm}^{2}\right.$ at $\left.50.3 \mathrm{bpm}\right)$ and acara $(17.13 \pm 1.11 \mathrm{mN} /$ $\mathrm{mm}^{2}$ at $\left.79.6 \mathrm{bpm}\right)$. Furthermore, treatment with ryanodine did not shift up- or downwards the force-frequency curve of acara. In contrast, this curve was shifted downwards (initial from $36.09 \pm 1.67$ to $28.34 \pm 2.44 \mathrm{mN} / \mathrm{mm}^{2}$ ) and also to the left (maximal regular contraction is decreased from 96 to $72 \mathrm{bpm}$ ) for jeju ventricle strips in response to ryanodine. At $50.3 \mathrm{bpm}$ (in vivo $f_{\mathrm{H}}$ ), the twitch force developed by the ventricle strips from jeju was decreased by $\cong 4 \mathrm{mN}$ (to $15.91 \pm 0.37 \mathrm{mN} / \mathrm{mm}^{2}$ ) after being treated with ryanodine.

When applied at steady-state contractions (12 bpm) after pre-treatment with $10 \mu \mathrm{M}$ of ryanodine, a tonic dose of adrenaline $\left(10^{-9} \mathrm{M}\right)$ failed to change inotropic responsiveness of the strips from both species (Table 1). However, when an adrenaline concentration usually observed in the plasma in response to stressful conditions $\left(10^{-6} \mathrm{M}\right)$ was added to the bath, strips from acara and jeju showed, respectively, $a \cong 50 \%$ and $\cong 225 \%$ increase in Fc under steady-state stimulation frequency.

Moreover, the force-frequency curves tended to be 
Table 1. Twitch force values ( $\mathrm{Fc}-\mathrm{mN} / \mathrm{mm} 2$, mean values \pm S.E.; $\mathrm{n}=12)$ developed by ventricle strips from acara and jeju at different stimulation frequencies (12, in vivo range, and $96 \mathrm{bpm}$ ) in response to different treatments. Ctrl: without previous addition of adrenaline or ryanodine; +Ryan: pre-treated with $10 \mu \mathrm{M}$ of ryanodine; T-Adr + Ryan: treated with 10-9 M of adrenaline and $10 \mu \mathrm{M}$ of ryanodine; A-Adr + Ryan: treated with 10-6 M of adrenaline and $10 \mu \mathrm{M}$ of ryanodine. I: irregular recording (i.e., at least $20 \%$ of preparations were unable to contract regularly at the respective frequency). *: different from the initial (12 bpm) frequency (ANOVA followed by Tukey-Kramer parametric test). A: different from Ctrl; b: different from + Ryan; c: different from T-Adr+Ryan; d: different from A-Adr+Ryan at the same stimulation frequency (Mann-Whitney non-parametric test). $\mathrm{p}<0.05$.

\begin{tabular}{|c|c|c|c|c|c|c|}
\hline \multirow[b]{2}{*}{ Treatment } & \multicolumn{3}{|c|}{ Acara } & \multicolumn{3}{|c|}{ Jeju } \\
\hline & 12 & $\begin{array}{c}79.6 \\
\text { in vivo }\end{array}$ & 96 & 12 & $\begin{array}{c}50.3 \\
\text { in vivo }\end{array}$ & 96 \\
\hline Ctrl & $28.66 \pm 1.86$ & $17.13 \pm 1.11^{*}$ & $14.06 \pm 1.87 *$ & $36.09 \pm 1.67$ & $20.40 \pm 0.94^{*}$ & $10.04 \pm 1.55^{*}$ \\
\hline + Ryan & $28.73 \pm 1.29$ & $20.02 \pm 1.18^{*}$ & $16.48 \pm 0.89 *$ & $28.34 \pm 2.44^{\mathrm{A}}$ & $15.91 \pm 1.37 *^{\mathrm{A}}$ & I \\
\hline T-Adr + Ryan & $32.95 \pm 1.32^{\mathrm{B}}$ & $33.30 \pm 1.33^{\mathrm{A}, \mathrm{B}}$ & $27.35 \pm 2.54^{* A, B}$ & $33.35 \pm 2.65$ & $20.15 \pm 1.60 *^{\mathrm{B}}$ & I \\
\hline A-Adr + Ryan & $44.27 \pm 4.93^{\mathrm{A}, \mathrm{B}, \mathrm{C}}$ & $33.57 \pm 3.74 * \mathrm{~A}, \mathrm{~B}$ & $26.40 \pm 2.07 * \mathrm{~A}, \mathrm{~B}$ & $92.16 \pm 7.91^{\mathrm{A}, \mathrm{B}, \mathrm{C}}$ & $69.51 \pm 5.97 * \mathrm{~A}, \mathrm{~B}$ & $42.88 \pm 5.81^{* \mathrm{~A}}$ \\
\hline
\end{tabular}

shifted upwards in response to adrenaline in both species (Fig. 2). At the in vivo frequency range (79.6 bpm), the twitch force developed by strips from acara was increased from $\cong 17 \mathrm{mN} / \mathrm{mm}^{2}$ (control) to $\cong 33 \mathrm{mN}$ in response to either $10^{-9}$ or $10^{-6} \mathrm{M}$ of adrenaline (Figs. 2b and $3 c ; n=12$ ). Interestingly, the negative force-frequency relationship observed in the ventricle from acara at both control and ryanodine-treated strips, tended to disappear specially after adding of a tonic dose $\left(10^{-9} \mathrm{M}\right)$ of adrenaline to the muscle bath, as shown in Fig. 2b. For jeju, $10^{-9} \mathrm{M}$ of adrenaline allowed the ventricle strips to recover the Fc developed before adding ryanodine $\left(\cong 20 \mathrm{mN} / \mathrm{mm}^{2}\right)$ at the in vivo frequency range (50.3 bpm; Fig. $3 \mathrm{~b}$ ), while the twitch force obtained in response to $10^{-6} \mathrm{M}$ of adrenaline was higher than that observed for control values at the in vivo frequency range $\left(69.51 \pm 5.97 \mathrm{mN} / \mathrm{mm}^{2} ; \mathrm{n}=12\right)$, as shown in Fig. 2c.

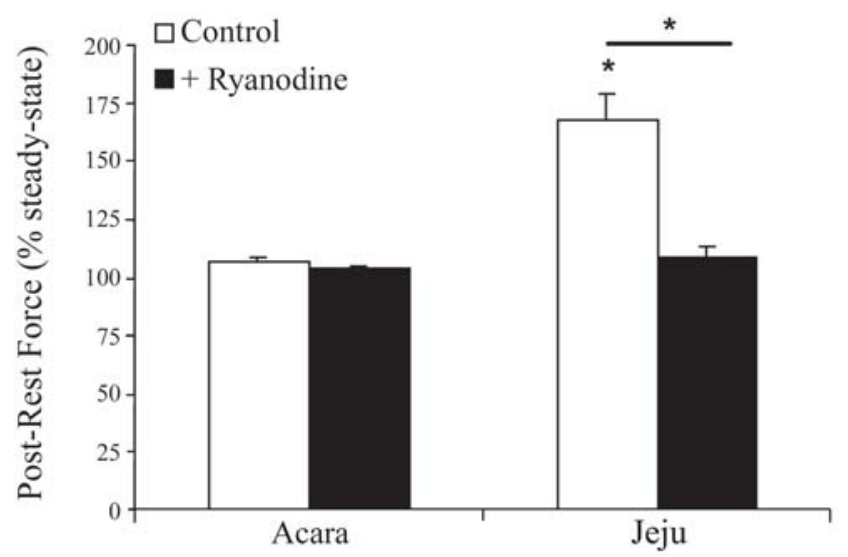

Fig. 1. Effect of $10 \mu \mathrm{M}$ of ryanodine on the force developed by ventricle strips from jeju $(n=12)$ and acara $(n=12)$ after a 5 min pause (Fc - \% of the force developed at $12 \mathrm{bpm}$; mean values \pm S.E.). The asterisk above the vertical bar denotes a difference in relation to the steady-state force (before rest) (ANOVA followed by Tukey-Kramer parametric test), while the asterisk above the horizontal line indicates the effect of ryanodine on the twitch force developed after the prolonged diastolic pause (Mann-Whitney non-parametric test). $\mathrm{p}<0.05$.

\section{Discussion}

In temperate teleosts it has been demonstrated that ryanodine channels remain in an "open state" over a longer period of time as a result of the lower testing temperatures (Hove-Madsen et al., 2001). This minimizes the role of the SR as a calcium source to the activation of myofibrils (Tiitu \& Vornanen, 2001). However, the myocytes of cold-adapted fish developed adaptive mechanisms that lead to a relative temperature-insensitivity of sarcolemmal $\mathrm{Ca}^{2+}$-transporting systems (particularly L-channels and NCX), maximizing the proportional contribution of transarcolemmal $\mathrm{Ca}^{2+}$ fluxes to the relaxation/contraction cycle (Tibbits et al., 1992; Xue et al., 1999; Kim et al., 2000; Shiels et al., 2000; Elias et al., 2001). This allows $\mathrm{Ca}^{2+}$ to be delivered to myosin at a rate and magnitude compatible with the low heart rates observed in cold-adapted fish (Farrell \& Jones, 1992; Driedzic \& Gesser, 1994; Lillywhite et al., 1999), assuring their survival in temperatures considered cardioplegic to endotherms, even without the direct participation of the SR in $\mathrm{Ca}^{2+}$ management.

In contrast, in very active temperate teleosts, as well as in tropical fish, which present considerably higher heart rates, a more direct participation of the SR in the E-C coupling in order to reduce the diffusion distances is predictable. A greater anatomic development of the SR, as well as a potential role of this organelle in the E-C coupling, has been described for rainbow trout, Oncorhynchus mykiss (Walbaum, 1792), especially at high temperatures and sub-physiological frequencies (Santer, 1974; Hove-Madsen \& Gesser, 1989; Hove-Madsen, 1992; Møller-Nielsen \& Gesser, 1992; Shiels \& Farrell, 1997; Aho \& Vornanen, 1998; Hove-Madsen et al., 1998; Lillywhite et al., 1999). Indeed, more recent studies (Harwood et al., 2000; Hove- Madsen et al., 2001) have also demonstrated a direct participation of the SR of trout in force development in more physiological conditions. An even higher contribution of the SR $\mathrm{Ca}^{2+}$ stores at physiological frequencies was described for the 'athletic' scombrids (tunas and mackerels) (Shiels et al., 2002). Corroborating these findings, Rivaroli et al. (2006) and Anelli Jr. et al. (2004) demonstrated the direct contribution of the SR to the ventricular inotropism at physiological frequencies and 
temperatures in two very active neotropical teleosts, the curimbata, Prochilodus lineatus (Valenciennes, 1837), and the pacu, Piaractus mesopotamicus (Holmberg, 1887), respectively.

On the other hand, other studies failed to demonstrate such a direct relationship among the level of activity and/or temperature $v$ s functionality of the SR. Ventricle strips from
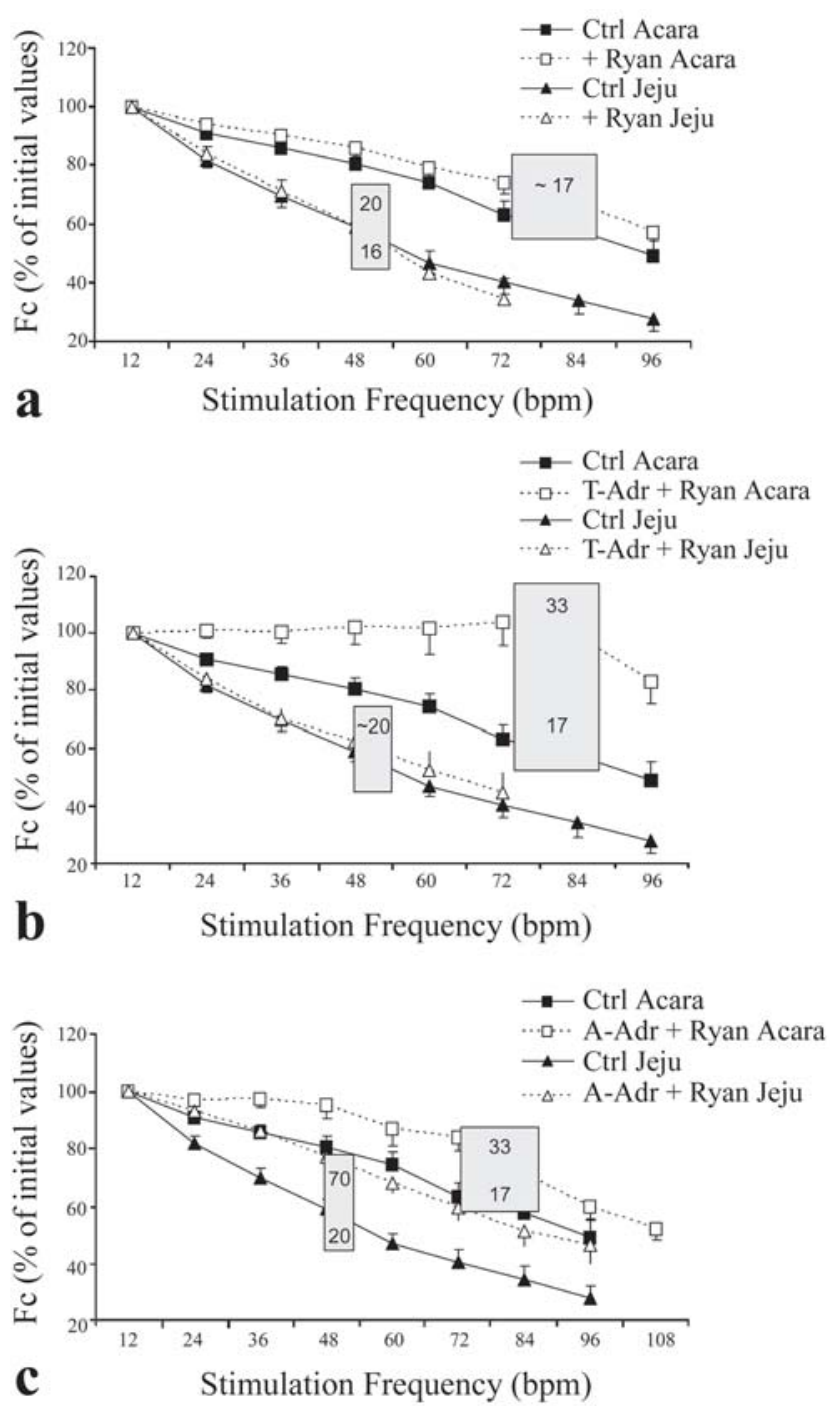

Fig. 2. Effect of increases in stimulation frequency on the force (FC - \% of initial values \pm S.E., $n=12$ ) developed by control preparations (black symbols) and after treatment with $10 \mu \mathrm{M}$ of ryanodine (a), after treatment with $10 \mu \mathrm{M}$ of ryanodine followed by an addition of $10^{-9} \mathrm{M}$ of adrenaline (b), or after treatment with $10 \mu \mathrm{M}$ of ryanodine followed by an addition of $10^{-6} \mathrm{M}$ of adrenaline (c) by ventricle strips from jeju (triangles) and acara (squares). The values inside the dashed squares close to the curves of each species denote the approximate absolute force (in $\mathrm{mN} / \mathrm{mm}^{2}$ ) registered at the frequencies measured in vivo for strips from jeju $\left(f_{\mathrm{H}}=50.3 \pm 2.7 \mathrm{bpm}\right)$ and acara $\left(f_{\mathrm{H}}=79.6 \pm 6.6\right.$ bpm). In (a), in spite of the similar curves obtained for jeju for both treatments, the absolute force was reduced by $\cong 4 \mathrm{mN}$ after treatment with ryanodine at the physiological frequency range (for statistics, see Table 1).
Nile tilapia, Oreochromis niloticus (Linnaeus, 1758), a species well-adapted to high temperatures such as $35^{\circ} \mathrm{C}$, or from fish that face acute transitions from 25 to more than $40^{\circ} \mathrm{C}$ in a few hours, such as the tide-pool goby Bathygobius soporator (Valenciennes, 1837), did not show a postrest potentiation of twitch force that could be inhibited by ryanodine, dismissing the SR participation, even at high temperatures and low frequencies (Rantin et al., 1998; Costa et al., 2000). Interestingly, both species (as well as acara) are tropical acanthopterygians, in which the E-C coupling has been shown to depend exclusively upon the extracellular $\mathrm{Ca}^{2+}$ sources at physiological (Fig. 2), and subphysiological (Fig. 1) frequencies. Moreover, it is worth mentioning that cichlids such as acara (South American) and Nile tilapia (African) have a common monophyletic origin (Kullander, 1998), presenting similar modes of life, levels of activity, and habitats.

Moreover, in some highly sedentary tropical fish, such as traira, Hoplias malabaricus (Bloch, 1794), studied by Olle (2003), and cascudo, Hypostomus regani (Ihering, 1905), studied by Rivaroli (2002), ryanodine exerted an inhibitory effect on inotropism at physiological temperatures (Fig. 3). Traira and jeju are erythrinid fish and show a similar reliance on SR $\mathrm{Ca}^{2+}$ stores.

Due to the fact that a functional SR was found in both sedentary (traira and cascudo) and active (curimbata and pacu) ostariophysian fish, it may be suggested that a

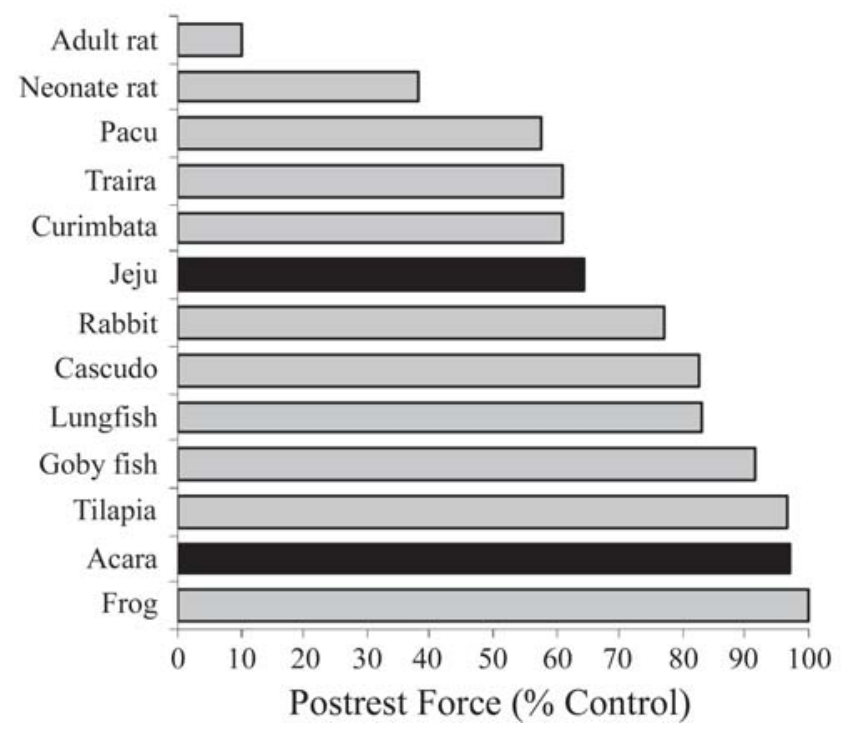

Fig. 3. Effect of $10 \mu \mathrm{M}$ of ryanodine on the force developed by ventricle strips from jeju $(n=12)$ and acara $(n=12)$ after a 5 min pause (Fc - \% control; mean values). The values obtained for jeju and acara (black bars) are compared to those described to other species (Rantin et al., 1998: tide-pool goby; Costa et al., 2000: tilapia; Bers, 2001: frog, Lithobates catesbeianus, Shaw, 1802; rabbit, adult and neonate rat; Rivaroli, 2002: cascudo; Rivaroli et al., 2006: curimbata; Olle, 2003: traira; Anelli Jr. et al., 2004: pacu; Costa et al., 2004: lungfish, Lepidosiren paradoxa Fitzinger, 1837) at $25^{\circ} \mathrm{C}$ (fish) or at room temperature (frog and mammals). 
functional SR is an ancestral trait of this group of tropical teleosts and not related only to the level of activity. In contrast, in tropical acanthopterygians, such as acara, Nile tilapia, and tide pool goby, the opposite seems to happen. Nevertheless, a larger variety of tropical species from the two superorders remain to be studied to prove the previous statement. The relative contribution of the $\mathrm{Ca}^{2+}$ stored in the SR of acara and jeju heart strips to force generation after a diastolic pause of $5 \mathrm{~min}$ is presented in Fig. 3, where it is compared to the results obtained to other species.

In spite of the species-specific variability in $\mathrm{SR} \mathrm{Ca}^{2+}$ dependency discussed previously, the strong positive inotropism caused by adding $10^{-6} \mathrm{M}$ of adrenaline to the muscle bath (Fig. 3c) fully compensated the SR blockade by ryanodine for the jeju ventricle strips and increased the twitch force even further which was observed for control preparations of both species. Moreover, when treated with a tonic dose of adrenaline $\left(10^{-9} \mathrm{M}\right)$, ventricle strips from jeju and acara were able to recover the twitch force observed before treatment with ryanodine when in vivo frequencies were reached (Table 1; Fig. 2b). This responsiveness to adrenaline demonstrates that both species, regardless of relying or not on intracellular $\mathrm{Ca}^{2+}$-stores to regulate the cardiac inotropism on a beat-tobeat basis, have developed mechanisms that assure the maintenance of inotropism. Additionally, as adrenaline was only applied in the presence of ryanodine, it cannot be excluded that it may have had a larger effect in the absence of ryanodine in ventricle strips from jeju.

In our experiments we studied the effects of adrenaline, even though adrenaline and noradrenaline are found in similar concentrations in the blood and heart tissue/nerve endings at rest (Abrahamsson \& Nilsson, 1978; Pennec \& LeBras, 1984). The selection of adrenaline as the sole adrenergic agonist was based on the fact that adrenaline is generally 10 times more effective than noradrenaline in stimulating $\beta$-adrenoceptors of fish hearts (Ask et al., 1981; Farrell et al., 1996).

The observed inotropic effects of adrenaline are complex. A redistribution of cellular $\mathrm{Ca}^{2+}$ is likely to be involved (Grossmann \& Furchgott, 1964; Niedergerke \& Page, 1977), as well as a stimulation of glycolysis (Williamson, 1964). The cardiac effects of adrenaline are mediated through a $\beta$ adrenoceptor signaling pathway that, in fish, involves $\beta_{2}$ adrenoceptors (Ask et al., 1981; Temma et al., 1986; Gamperl et al., 1994).

There are several mechanisms of adrenergic modulation for heart performance and some of them are relevant to the regulation of inotropism. The stimulation of $\beta$-adrenergic receptors causes the phosphorylation of the SL L-type $\mathrm{Ca}^{2+}$ channels (Shiels et al., 1998) and also stimulates $\mathrm{Na}^{+} / \mathrm{K}^{+}-$ exchanger (Hove-Madsen \& Gesser, 1989), increasing transarcolemmal Ca ${ }^{2+}$ fluxes. Furthermore, Boller \& Pott (1989) demonstrated that $\mathrm{Ca}^{2+}$ transportation through SR is also increased by catecholamines in mammalian hearts. However, given that in our experiments SR function was blocked by ryanodine previously to adrenaline addition, the effects of adrenaline could be attributed only to increases in $\mathrm{Ca}^{2+}$ transportation through sarcolemma.

In contrast to what is described to birds and mammals, in which adrenaline is unable to compensate the negative effect of SR blockade by solely increasing sarcolemmal $\mathrm{Ca}^{2+}-$ transportation, a $\beta$-adrenergic stimulation in response to stressful conditions in ventricle strips from jeju can potentially enhance the inotropic responsiveness of the heart when increases on cardiac performance are required. Considering the previous observations, it can be suggested that the ventricular myocytes of acara depend exclusively on extracellular $\mathrm{Ca}^{2+}$, while intracellular $\mathrm{Ca}^{2+}$-stores seem to be relatively important to force development in the ventricle from jeju. In the former, adrenaline simply improves transarcolemmal $\mathrm{Ca}^{2+}$ fluxes, while in the latter it could potentially act on sarcolemmal and SR fluxes.

\section{Acknowledgements}

This study was supported by FAPESP (Proc. 2002/141893 and 2003/08238-4). The authors would like to thank Mr. Nelson Matos (in memoriam) for the animal collection and laboratory care. All the experiments were performed complying with the Brazilian laws.

\section{Literature Cited}

Abrahamsson, T. \& S. Nilsson. 1978. Control of catecholamine release from cromafim tissue in a teleosts fish. Pp. 247-252. In: Schmidt-Nielsen, K., L. Bolis \& S. Meddrell (Eds.). Comparative Physiology - Water, Ion and Fluid Mechanics. Cambridge, Cambridge University Press, 346p.

Aho, E. \& M. Vornanen. 1998. $\mathrm{Ca}^{2+}$-ATPase activity and $\mathrm{Ca}^{2+}$ uptake by sarcoplasmic reticulum in fish heart: effects of thermal acclimation. Journal of Experimental Biology, 201: 252-232.

Anelli-Jr, L. C., C. D. Olle, M. J. Costa, F. T. Rantin \& A. L. Kalinin. 2004. Effects of temperature and calcium availability on ventricular myocardium from the neotropical teleost Piaractus mesopotamicus (Holmberg 1887 - Teleostei, Serrasalmidae). Journal of Thermal Biology, 29: 103-113.

Ask, J. A., G. Stene-Larsen \& K. B. Helle. 1981. Temperature effects on the $\beta_{2}$-adrenoceptors of the trout atrium. Journal of Comparative Physiology, 143: 161-168.

Bers, D. M. 2001. Excitation-contraction coupling and cardiac contractile force. Dordrecht, Kluwer Academic Publishers, 426p.

Boller, M. \& L. Pott. 1989. $\beta$-Adrenergic modulation of transient inward current in guinea-pig cardiac myocytes. Pflügers Archives (European Journal of Physiology), 415: 276-288.

Butler, P. J., J. D. Metcalfe \& S. A. Ginley. 1986. Plasma catecholamines in the lesser spotted dogfish and rainbow trout at rest and during different levels of exercise. Journal of Experimental Biology, 123: 409-421.

Coronado, R., J. Morrissette, M. Sukhareva \& D. M. Vaughan. 1994. Structure and function of ryanodine receptors. American Journal of Physiology, 246(35): 1485-1504.

Costa, M. J., C. D. Olle, A. L. Kalinin \& F. T. Rantin. 2004. Role of the sarcoplasmic reticulum in calcium dynamics of the ventricular myocardium of Lepidosiren paradoxa (Dipnoi) at different temperatures. Journal of Thermal Biology, 29: 81-89. 
Costa, M. J., L. Rivaroli, F. T. Rantin \& A. L. Kalinin. 2000. Cardiac tissue function of the teleost fish Oreochromis niloticus under different thermal conditions. Journal of Thermal Biology, 25: 373-379.

Driedzic, W. R. \& H. Gesser. 1994. Energy metabolism and contractility in ectothermic vertebrate hearts: hypoxia, acidosis, and low temperature. Physiological Reviews, 74(1): 221-258.

Elias, C. L., X. H. Xue, C. R. Marshall, A. Omelchenko, L. V. Hryshki \& G. F. Tibbits. 2001. Temperature dependence of cloned mammalian and salmonid cardiac $\mathrm{Na}^{+} / \mathrm{Ca}^{2+}$ exchanger isoforms. American Journal of Physiology, 281: 993-1000.

Fabiato, A. 1983. Calcium-induced release of calcium from the cardiac sarcoplasmic reticulum. American Journal of Physiology, 245(14): 1-14.

Farrell, A. P. 1984. A review of cardiac performance in the teleost heart: intrinsic and humoral regulation. Canadian Journal of Zoology, 62: 523-536.

Farrell, A. P., A. K. Gamperl, J. M. T. Hicks, H. A. Shiels \& K. E. Jain. 1996. Maximum cardiac performance of rainbow trout (Oncorhynchus mykiss) at temperatures approaching their upper lethal limit. Journal of Experimental Biology, 199: 663-672.

Farrell, A. P. \& D. R. Jones. 1992. The Heart. Pp. 1-88. In: Hoar, W. S., D. J. Randall \& A. P. Farrell (Eds.). Fish Physiology: The Cardiovascular System (v. 12A). New York, Academic Press, 340p.

Gamperl, A. K., M. Wilkinson \& R. G. Boutilier. 1994. Betaadrenoceptors in the trout (Oncorhynchus mykiss) heart: characterization, quantification, and effects of repeated catecholamine exposure. General and Comparative Endocrinology, 95: 259-272.

Glass, M. L., F. T. Rantin, R. M. M. Verzola, M. N. Fernandes \& A. L. Kalinin. 1991. Cardio-respiratory synchronization and myocardial function in hypoxic carp (Cyprinus carpio L.). Journal of Fish Biology, 39: 143-149.

Grossmann, A. \& R. F. Furchgott. 1964. The effects of various drugs on calcium exchange in the isolated guinea-pig left auricle. Journal of Pharmacology and Experimental Therapeutics, 145: 162-172.

Harwood, C. L., F. C. Howarth, J. D. Altringham \& E. White. 2000. Rate-dependent changes in cell shortening, intracellular $\mathrm{Ca}^{2+}$ levels and membrane potential in single, isolated rainbow trout (Oncorhynchus mykiss) ventricular myocytes. Journal of Experimental Biology, 203: 493-504.

Hove-Madsen, L. 1992. The influence of temperature on ryanodine sensitivity and the force-frequency relationship in the myocardium of rainbow trout. Journal of Experimental Biology, 167: 47-60.

Hove-Madsen, L. \& H. Gesser. 1989. Force-frequency relation in the myocardium of rainbow trout: effects of $\mathrm{K}^{+}$and adrenaline. Journal of Comparative Physiology B, 159: 61-69.

Hove-Madsen, L., A. Llach \& L. Tort. 1998. Quantification of $\mathrm{Ca}^{2+}$ uptake in the sarcoplasmic reticulum of trout ventricular myocytes. American Journal of Physiology, 275(44): 2070-2080.

Hove-Madsen, L., A. Llach \& L. Tort. 2001. The function of the sarcoplasmic reticulum is not inhibited by low temperatures in trout atrial myocytes. American Journal of Physiology, 281: 1902-1906.

Keen, J. E., A. P. Farrell, G. F. Tibbits \& R. W. Brill. 1992. Cardiac physiology in tunas. II. Effect of ryanodine, calcium, and adrenaline on force-frequency relationship in atrial strips from skipjack tuna, Katsuwonus pelamis. Canadian Journal of Zoology, 70: 1211-1217.

Keen, J. E., D. M. Vianzon, A. P. Farrell \& G. F. Tibbits. 1994. Effect of temperature and temperature acclimation on the ryanodine sensitivity of the trout myocardium. Journal of Comparative Physiology B, 164: 438-443.
Kim, C., M. Coyne \& J. Gwathmey. 2000. Voltage-dependent calcium channels in ventricular cells of rainbow trout: effect of temperature changes in vitro. American Journal of Physiology, 278: 1524-1534.

Kullander, S. O. 1998. A phylogeny and classification of the South American Cichlidae (Teleostei: Perciformes). Pp. 461-498. In: Malabarba, L. R., R. E. Reis, R. P. Vari, Z. M. S. Lucena \& C. A. S. Lucena (Eds.). Phylogeny and Classification of Neotropical Fishes. Porto Alegre, Edipucrs, 603p.

Lillywhite, H. B., K. C. Zippel \& A. P. Farrell. 1999. Resting and maximal heart rates in ectothermic vertebrates. Comparative Biochemistry and Physiology A, 124: 369-382.

Møller-Nielsen, T. \& H. Gesser. 1992. Sarcoplasmic reticulum and excitation-contraction coupling at 20 and $10{ }^{\circ} \mathrm{C}$ in rainbow trout myocardium. Journal of Comparative Physiology B, 162: 526534.

Nayler, W. G., P. Daile, D. Chipperfield \& K. Gan. 1970. Effect of ryanodine on calcium in cardiac muscle. American Journal of Physiology, 219: 1620-1626.

Niedergerke, R. \& S. Page. 1977. Analysis of catecholamine effects in single atrial trabeculae of the frog heart. Proceedings of the Royal Society B (Biological Sciences), 197(1128): 333-362.

Olle, C. D. 2003. Função cardíaca do teleósteo Hoplias malabaricus (Teleostei, Erythrinidae) submetido a diferentes condições térmicas. Unpublished MSc. Dissertation. Universidade Federal de São Carlos, São Carlos, 94p.

Pennec, J. P. \& Y. M. LeBras. 1984. Storage and release of catecholamines by nervous endings in the isolated heart of eel (Anguilla anguilla L.). Comparative Biochemistry and Physiology C, 77: 167-172.

Rantin, F. T., H. Gesser, A. L. Kalinin, C. D. R. Guerra, J. C. Freitas \& W. R. Driedzic. 1998. Heart performance, $\mathrm{Ca}^{2+}$ regulation and energy metabolism at high temperatures in Bathygobius soporator, a tropical, marine teleost. Journal of Thermal Biology, 23(1): 31-39.

Rantin, F. T., M. L. Glass, A. L. Kalinin \& R. M. M. Verzola. 1993. Cardio-respiratory responses in two ecologically distinct erythrinids (Hoplias malabaricus and Hoplias lacerdae) exposed to graded environmental hypoxia. Environmental Biology of Fish, 36: 93-97.

Rivaroli, L. 2002. Respostas cronotrópicas e inotrópicas do miocárdio ventricular de três espécies de peixes tropicais ecologicamente distintas: curimbatá, Prochilodus lineatus, traíra, Hoplias malabaricus, e cascudo, Hypostomus regani. Unpublished MSc. Dissertation. Universidade Federal de São Carlos, São Carlos, 77p.

Rivaroli, L., F. T. Rantin \& A. L. Kalinin. 2006. Cardiac function of two ecologically distinct Neotropical freshwater fish: Curimbata, Prochilodus lineatus (Teleostei, Prochilodontidae), and trahira, Hoplias malabaricus (Teleostei, Erythrinidae). Comparative Biochemistry and Physiology A, 145(3): 322-327.

Rousseau, E., J. S. Smith \& G. Meissner. 1987. Ryanodine modifies conductance and gating behavior of single $\mathrm{Ca}^{2+}$ release channel. American Journal of Physiology, 253(22): 364-368.

Santer, R. M. 1974. The organization of the sarcoplasmic reticulum in teleost ventricular myocardial cells. Cell and Tissue Research, 151: 395-402.

Shiels, H. A. \& A. P. Farrell. 1997. The effect of temperature and adrenaline on the relative importance of the sarcoplasmic reticulum in contributing $\mathrm{Ca}^{2+}$ to force development in isolated ventricular trabeculae from rainbow trout. Journal of Experimental Biology, 200: 1607-1621. 
Shiels, H. A., E. V. Freund, A. P. Farrell \& B. A. Block. 1999. The sarcoplasmic reticulum plays major role in atrial muscle of yellowfin tuna. Journal of Experimental Biology, 202: 881-890.

Shiels, H. A., E. D. Stevens \& A. P. Farrell. 1998. Effect of temperature, adrenaline and ryanodine on power production in trout (Oncorhynchus mykiss) ventricular trabeculae. Journal of Experimental Biology, 201: 2701-2710.

Shiels, H. A., M. Vornanen \& A. P. Farrell. 2000. Temperaturedependence of L-type $\mathrm{Ca}^{2+}$ channel in atrial myocytes from rainbow trout. Journal of Experimental Biology, 203: 2771-2780.

Shiels, H. A., M. Vornanen \& A. P. Farrell. 2002. Effects of temperature on intracellular $\left[\mathrm{Ca}^{2+}\right]$ in trout atrial myocytes. Journal of Experimental Biology, 205: 3641-3650.

Temma, K., T. Hirata, T. Kitazawa, N. Kondo \& Y. Katano. 1986. Are beta-adrenergic receptors in ventricular muscles of carp heart (Cyprinus carpio) mostly of beta-2 type? Comparative Biochemistry and Physiology C, 83: 261-263.

Thomas, M. J., B. N. Hamman \& G. F. Tibbits. 1986. Dihydropyridine and ryanodine binding in ventricles from rat, trout, dogfish and hagfish. Journal of Experimental Biology, 199: 1999-2009.

Tibbits. G. 1996. Towards a molecular explanation of the high performance of the tuna heart. Comparative Biochemistry and Physiology A, 113: 77-82.

Tibbits, G. F., L. Hove-Madsen \& D. M. Bers. 1991. Calcium transport and the regulation of cardiac contractility in teleosts: a comparison with higher vertebrates. Canadian Journal of Zoology, 69: 2014-2019.

Tibbits, G. F., K. D. Philipson \& H. Kashihara. 1992. Characterization of myocardial $\mathrm{Na}^{+}-\mathrm{Ca}^{2+}$ exchange in rainbow trout. American Journal of Physiology, 262(31): 411-417.

Tiitu, V. \& M. Vornanen. 2001. Cold adaptation suppresses the contractility of both atrial and ventricular muscle of the crucian carp heart. Journal of Fish Biology, 59: 141-156.

Vornanen, M. 1996. Effect of extracellular calcium on the contractility of warm- and cold-acclimated crucian carp heart. Journal of Comparative Physiology B, 165: 507-517.

Williamson, J. R. 1964. Metabolic effects of epinephrine in the isolated perfused rat heart. Journal of Biological Chemistry, 239: 2721-2729.

Xue, X. H., L. V. Hryshko, D. A. Nicoll, K. D. Philipson \& G. F. Tibbits. 1999. Cloning, expression, and characterization of the trout cardiac $\mathrm{Na}^{+} / \mathrm{Ca}^{2+}$ exchanger. American Journal of Physiology, 277(46): 693-700.

Accepted August 2, 2009

Published September 30, 2009 